\title{
Cautionary optimism: caffeine and Parkinson's disease risk
}

Leonard L. Sokol ${ }^{1 \dagger}$, Michael J. Young ${ }^{2 \dagger}$, Alberto J. Espay ${ }^{1}$ and Ronald B. Postuma ${ }^{3^{*}}$

\begin{abstract}
Most Parkinson's disease (PD) patients present without known family history and without a diagnosed prodromal phase, underscoring the difficulty of employing primary (neuroprevention) and secondary (neuroprotection) preventions. In cases of monogenic forms, however, potential gene-carrying family members of a proband could engage in neuroprevention, such as exercise or diet modifications, to attenuate the risk of, or delay, disease development. However, a historical lack of recognized disease-modifying interventions has limited clinicians' ability to recommend reliable preventive measures in caring for at-risk populations. We briefly analyze the first retrospective study to examine caffeine consumption and PD risk in a LRRK2 R1628P cohort.
\end{abstract}

Keywords: Parkinson's disease, LRRK2, Caffeine, Risk factors

\section{Letter to the Editor}

Caffeine is strongly associated with reduced risk of Parkinson's disease (PD). Meta-analyses [1,2] suggest that non-users have a higher PD risk in a notably dosedependent fashion [2]. The underlying mechanism for this apparent effect is unclear. Potential explanations include a true neuroprotective benefit (supported by some animal models finding benefits of $A_{2 A}$ antagonism [3]), a symptomatic effect which delays diagnosis (supported by preliminary evidence of motor benefit of caffeine in small randomized controlled trials [4]), reverse confounding (prodromal parkinsonism reduces caffeine intake via changes in tolerability or reward mechanisms such as has been suggested for smoking [5]), or confounding by another unmeasured factor (e.g., the putative Parkinson personality [6]).

Most recently, a new case-control study [7] examined caffeine consumption and PD risk in a gene-carrier (LRRK2 R1628P) cohort of Chinese patients. LRRK2 $\mathrm{R} 1628 \mathrm{P}$ is a low-penetrance variant that has been associated with increased PD risk in mainly Asian populations, with an odds ratio (OR) ranging from 1.20 to 2.83 [8]. The study included 378 PD subjects and 434 healthy controls (PD median age: 66 years; controls: 60). For OR

\footnotetext{
* Correspondence: ron.postuma@mcgill.ca

${ }^{\dagger}$ Equal contributors

${ }^{3}$ Department of Neurology, L7-305 Montreal General Hospital, 1650 Cedar

Avenue, Montreal, QC H3G1A4, Canada

Full list of author information is available at the end of the article
}

calculations, the authors defined the reference group (PD cases: 257; controls: 369) as those with the LRRK2 wildtype allele who had a reported history of caffeine consumption. Gene-carrier caffeine-abstainers had a 15.4 (95\% CI = 1.94,122.3, $n=11)$ OR of PD; by contrast, gene-carrier caffeine-consumers had a lower increased OR of $3.07(2.02-4.66, n=33)$. On the basis of these data, the study authors suggest that caffeine intake may be associated with reduced risk of PD development especially in those who are gene-carriers.

Some caveats should be considered when interpreting these results. First, the sample size was insufficient to provide an estimate of a true effect, as within the R1628P sample, there were too few PD cases $(n=28 ; 18$ caffeineconsumers and 10 caffeine-abstainers) and controls ( $n=16 ; 15$ caffeine-consumers and 1 caffeine-abstainer), yielding an imprecise OR (1.94 to 122.3$)$ that clearly overlapped with the OR for gene-carrier caffeine-consumers. Second, recall bias or other sources of measurement error may have influenced the interpretation of the PD environmental risk factor questionnaire. Third, it is unclear what number of multiple hypotheses were tested in this cohort; if dozens of potential gene-environment interactions were queried, the chances of a spurious result are high. It should be cautioned that many gene-environment findings based upon single cohort studies are not reproduced. Finally, the physiologic mechanism(s) governing the putative impact of caffeine in the PD neurodegenerative cascade 
remains unclear. Recognizing the excitement that the prima-facie favorable findings of this study may generate among patients and clinicians, these key caveats should be considered in the course of crafting an evidence-based and patient-centered approach to neuropreventive counseling and care.

While this study was neither definitive nor generalizable, it suggests the possibility that disease subtypes may have different environmental risk profiles. Of note, LRRK2 in PD is characterized by inconsistent deposition of synuclein, and a corresponding lower prevalence of non-motor manifestation such as REM sleep behavior disorder (RBD) and dementia [9]. A recent case control study of patients with idiopathic RBD found that caffeine use did not protect against future development of PD; this is the only prospective study that has ever failed to find a caffeine effect [10]. If there is an RBD subtype of PD that does not respond to caffeine, then might non-RBD subtypes respond even more?

If such a study is replicated in a larger series-which is critical for ascertainment of such gene-environmental interactions-it may have implications for other wellknown LRRK2 variants, such as G2019S, which has a calculated disease penetrance of $26 \%$ by age 80 [11]. Might caffeine have a similar interaction? If so, might such patients benefit from using caffeine? Without better evidence, there remain dichotomous perspectives $[12,13]$ on how to counsel carriers and their families. Research that examines how environmental behaviors might attenuate PD susceptibility is warranted [11], as is further investigation on how to counsel such a vulnerable cohort [14].

\section{Statement on ethics approval and consent to participate}

Not applicable.

\section{Statement of consent for publication}

Not applicable.

\section{Availability of data and materials \\ Not applicable.}

\begin{abstract}
Abbreviations
LRRK2: leucine-rich repeat kinase 2; OR: odds ratio; PD: parkinson's disease; RBD: REM sleep behavior disorder.
\end{abstract}

\section{Competing interests}

Financial disclosures related to research covered in this article: The authors report no conflicts of interest related to research covered in this article.

\section{Authors' contributions}

All authors read and approved of the final manuscript. (1) Letter: A. Conception, B. Organization, C. Execution; (2) Manuscript: A. Writing of the First Draft, B. Review and Critique. LLS: 1A, 1B, 1C, 2A. MJY: 1B, 1C, 2A. AJE: 1B, 1C, 2B. RBP: 1B, 1C, 2B.
Funding

Not applicable.

\section{Full financial disclosures}

L.L. Sokol has nothing to disclose. M.J. Young has nothing to disclose.

A.J. Espay serves on scientific advisory boards for Solvay (now Abbvie), Chelsea Therapeutics, TEVA, Impax, Merz, Pfizer, Solstice Neurosciences, Eli Lilly, Acadia, and USWorldMeds; serves as an Associate Editor of the Journal of Clinical Movement Disorders and on the editorial boards of Parkinsonism and Related Disorders and The European Neurological Journal; receives publishing royalties from Lippincott Williams \& Wilkins and Cambridge University Press; serves as a consultant for Chelsea Therapeutics, Cynapsus, Lundbeck, Abbvie, and Acadia; serves on speakers' bureaus for UCB, TEVA, American Academy of Neurology, and the Movement Disorders Society; has received honoraria from UCB, TEVA, Acadia, the American Academy of Neurology, and the Movement Disorders Society; and receives research support from the NIH, CleveMed/Great Lakes Neurotechnologies, and the Michael J. Fox Foundation. R.B. Postuma received grants from the Fonds de la Recherche en Sante Quebec, the Canadian Institute of Health Research, the Parkinson Society of Canada, the Weston-Garfield Fundation, and the Webster Foundation, as well as funding for consultancy from Biotie and Roche and speaker fees from Novartis Canada and Teva Neurosciences.

\section{Author details}

'Department of Neurology, James J and Joan A. Gardner Center for Parkinson's disease and Movement Disorders, University of Cincinnati, Cincinnati, OH, USA. ${ }^{2}$ Harvard Medical School, Boston, MA, USA. ${ }^{3}$ Department of Neurology, L7-305 Montreal General Hospital, 1650 Cedar Avenue, Montreal, QC H3G1A4, Canada.

Received: 26 February 2016 Accepted: 11 May 2016

Published online: 06 June 2016

\section{References}

1. Costa J, Lunet N, Santos C, Santos J, Vaz-Carneiro A. Caffeine exposure and the risk of Parkinson's disease: a systematic review and meta-analysis of observational studies. J Alzheimers Dis. 2010;20 Suppl 1:S221-38.

2. Qi H, Li S. Dose-response meta-analysis on coffee, tea and caffeine consumption with risk of Parkinson's disease. Geriatr Gerontol Int. 2014;14:430-9.

3. Schwarzschild MA, Xu K, Oztas E, Petzer JP, Castagnoli K, Castagnoli N, Chen J-F. Neuroprotection by caffeine and more specific A2A receptor antagonists in animal models of Parkinson's disease. Neurology. 2003:61(11 Suppl 6):S55-61.

4. Postuma RB, Lang AE, Munhoz RP, Charland K, Pelletier A, Moscovich M, Filla L, Zanatta D, Rios Romenets S, Altman R, Chuang R, Shah B. Caffeine for treatment of Parkinson disease: a randomized controlled trial. Neurology. 2012;79:651-8.

5. Ritz B, Lee P-C, Lassen CF, Arah OA. Parkinson disease and smoking revisited: ease of quitting is an early sign of the disease. Neurology. 2014;83:1396-402.

6. Ishihara $L$, Brayne $C$. What is the evidence for a premorbid parkinsonian personality: a systematic review. Mov Disord. 2006;21:1066-72.

7. Kumar PM, Paing SST, Li H, Pavanni R, Yuen Y, Zhao Y, Tan EK. Differential effect of caffeine intake in subjects with genetic susceptibility to Parkinson's Disease. Sci Rep. 2015;5(November):15492.

8. Ross OA, Wu YR, Lee MC, Funayama M, Chen ML, Soto Al, Mata IF, Lee-Chen GJ, Chiung MC, Tang M, Zhao Y, Hattori N, Farrer MJ, Tan EK, Wu RM. Analysis of Lrrk2 R1628P as a risk factor for Parkinson's disease. Ann Neurol. 2008;64:88-92.

9. Kalia LV, Lang AE, Hazrati L-N, Fujioka S, Wszolek ZK, Dickson DW, Ross OA, Van Deerlin VM, Trojanowski JQ, Hurtig HI, Alcalay RN, Marder KS, Clark LN, Gaig C, Tolosa E, Ruiz-Martínez J, Marti-Masso JF, Ferrer I, de Munain L, Goldman SM, Schüle B, Langston JW, Aasly JO, Giordana MT, Bonifati V, Puschmann A, Canesi M, Pezzoli G, Maues De Paula A, Hasegawa K, et al. Clinical correlations with Lewy body pathology in LRRK2-related Parkinson disease. JAMA Neurol. 2015;72:100-5.

10. Postuma RB, Iranzo A, Hogl B, Arnulf I, Ferini-Strambi L, Manni R, Miyamoto T, Oertel W, Dauvilliers Y, Ju Y El, Puligheddu M, Sonka K, Pelletier A, Santamaria J, Frauscher B, Leu-Semenescu S, Zucconi M, Terzaghi M, Miyamoto M, Unger MM, Carlander B, Fantini ML, Montplaisir JY.. Risk factors for neurodegeneration 
in idiopathic rapid eye movement sleep behavior disorder: A multicenter study. Ann Neurol. 2015;77:830-9.

11. Marder K, Wang Y, Alcalay RN, Mejia-Santana H, Tang MX, Lee A, Raymond D, Mirelman A, Saunders-Pullman R, Clark L, Ozelius L. Age-specific penetrance of LRRK2 G2019S in the Michael J. Fox Ashkenazi Jewish LRRK2 Consortium. Neurology. 2015;85(1):89-95. https://www.ncbi.nlm.nih.gov/ pubmed/?term=26062626.

12. Pont-Sunyer C, Bressman S, Raymond D, Glickman A, Tolosa E, SaundersPullman R. Disclosure of research results in genetic studies of Parkinson's disease caused by LRRK2 mutations. Mov Disord. 2015;00:n/a-a.

13. Giladi N, Mirelman A, Thaler A, Bar-Shira A, Gurevich T, Orr-Urtreger A. Fighting the risk of developing Parkinson's disease; clinical counseling for first degree relatives of patients with Parkinson's disease. J Neurol Sci. 2011;310:17-20.

14. Young MJ. Peering into Vulnerable Genes: Genetic Risk and Population Screening. Narrat Inq Bioeth. 2015;5(3):222. https://www.ncbi.nlm.nih.gov/ pubmed/?term $=26752575$.

Submit your next manuscript to BioMed Central and we will help you at every step:

- We accept pre-submission inquiries

- Our selector tool helps you to find the most relevant journal

- We provide round the clock customer support

- Convenient online submission

- Thorough peer review

- Inclusion in PubMed and all major indexing services

- Maximum visibility for your research

Submit your manuscript at www.biomedcentral.com/submit
Biomed Central 